\title{
NESTS AND NEST-BUILDING IN BIRDS: PART II
}

FRANCIS H. HERRICK

Western Reserve University, Cleveland, Ohio

EIGHT FIGURES

\section{CONTENTS}

4. Analysis of Increment Nests on the Basis of Behavior. Position of the Nest. Uniformity in Selection of Nesting Site Do Birds in Nesting seek "the Protection of Man?" Individual Change in Nest Site Size of the Nest. Double, Compound or Superimposed Nests The Materials of Nests and their Method of Arrangement Appropriation of Nest Materiale illustrated.

5. Variations in the Nests of Certain Birds. Variation in the Red-eyed Vireo. Variation in the Wood Pewee. Variation in Hummingbirds' Nests.

The descriptive literature of birds' nests, which is extended to great length, is chiefly concerned with their size, position, and general environment, as well as with the kinds of material used in construction. When certain species are considered the recorded variations in respect to most of these characters are both numerous and striking.

The highest order of constructive effort exhibited by modern birds is embodied in the increment nests of either statant or pendent types. Thousands of species, many of which represent the highest existing order of Passeres build more or less elaborately after this general fashion, according to their specific modes.

We shall first attempt to give a general analysis of increment nests in order to ascertain their more uniform and more important characteristics from the standpoint of behavior, as well as to determine the significance of the variations to which they are subject. No pretense is made of offering more than a suggestive outline, for seldom has it happened that all the conditions under which a given nest was built were even approximately known.

4. ANALYSIS OF INCREMENT NESTS ON THE BASIS OF BEHAVIOR

In considering the behavior characteristic of the builder in any species of birds, the following marks of the finished nest have special significance: (I) The form and dimensions of 
the inner wall, or in other words the diameter, depth, and symmetry of the "cup," 20 which are its most constant and valuable characters, especially in the statant nest; (2) The form and treatment of the outer wall which is characteristic of many nests of either type; (3) The arrangement of the materials used in construction, or the way in which they are put together, but it should be noted that our information under this head can never be reliable or complete without careful observations on the builders at work These several characters are the most important marks of increment nests because the uniformity which they present in all individuals of a given species is very marked, being the result of uniform methods of building.

The following characters, with notable exceptions, are less constant because subject to a greater number of modifying influences; (4) The kind of materials used in construction, which are commonly variable, being as a rule drawn from the nearest source; (5) The size or weight of the nest, which is most constant in the pendent group, but subject to wide variation in nearly all which are supported from below, and (6) finally the position, which is notoriously subject to wide fluctuation in a great number of species. By "position" we mean the kind of support or immediate environment, as well as the point in space, in reference to the surface of the ground, which the nest occupies.

It will be most convenient to notice the several characters enumerated in inverse order, since the uniformity of the outer and inner walls will he illustrated by specific cases later. (See section 5.)

Position of the nest. We might say with a degree of truth that adequate support required for a nest in a given case is usually a prime factor in determining its position. To give an immediate illustration: the mourning dove (see fig. I, part I) commonly builds its shallow platform within ro feet of the ground but at the present moment a pair of this species is occupying a nest at a height of nearly 40 feet. It is placed in the crotch of a maple tree, $x_{5}$ feet from a house and above the level

\footnotetext{
${ }^{20} \mathrm{It}$ is common to speak of the outer and inner surfaces of a nest as its "walls," which meet at the "rim;" the "inner wall " will often be designated the "cup." There is properly but one wall, the inner surface of which corresponds to the cup. when the word is used in this sense
} 
of its attic windows. ${ }^{21}$ Now the interesting fact to notice in the case of these doves is that, as often happens, they used the remains of an old robin's nest as the foundation for their own. The presence of such a ready made support evoked in them the building responses, and it is safe to say that the old nest at that particular point and indeed in that particular tree determined the presence of the new one. We may add in passing that this nest was begun by the male on April 16, and finished by him on the following day; it was composed mainly of roots taken from a freshly dug trench close to the tree.

While certain species habitually nest high and others low; the question of vertical height is unimportant within limits. These limits, moreover, are determined by other habits and would be greater in high flying doves than in cuckoos, which keep closer to the ground. Unimportant too in many cases is the nature of the support, for we cannot credit the bird with man's concept of " natural," as distinguished from " artificial " structures.

While we appreciate the futility of drawing general conclusions upon most phases of this subject without taking refuge in the proriso that some species or individuals are likely to vary more and others less, we shall endeavor to consider the problem from the standpoint of the bird, and first in the case of the robin, the cuckoo, and the chimney swift.

The robin in nest-building looks primarily for a good support, that is good in both the physical and biological sense, or suitable in reference to its methods of construction and other habits; since such supports abound great variation in this respect is inevitable; now we find its nest close to the ground or even upon it, now in the crotch of a mere sapling or saddled to the high horizontal branch of an apple tree or elm. I have seen the robin nesting on the end of a stick which a farmer had set against his barn, on the stump of a tree recently felled, as well as against the protecting side of the corded wood to which a tree had been reduced; then it may build on a roof-gutter when it is liable to be disturbed by the householder, on a porch shelf, or on a neat bracket set against the wall of house or barn expressly for its use. Many such sites eroke in certain individual robins the same kind of response, and many are chosen in consequence.

"I For calling my attention to this nest I am indebted to Mrs. Robert Ruedy, of Cleveland Heights Village, Ohio. 
Though such supports as the last named are good for robins, they would be rery poor for cuckoos in relation to their feeding and other habits, and would never be taken. Such, moreover, might not appeal to certain robins, when the circumstances of their birth or experience had lerl them far from the haunts of man.

The black-billed cuckoo (Coccygus erythropthalmus) so far as I have observed in central New Hampshire builds only in sapling white pines, stunted crabs and thorn apple bushes, the trat recorded variation in height of nest in this species for the entire country being only $x 6$ feet $(25$ inches to 18 feet). This remarkable constancy in position, or as to height and immediate environment, is plainly determined by the habits of the birds when on their breeding and feeding grounds. We have only to recall the stealthy, stalking manner of life of this cuckoo, which keeps near to the ground, and inhabits pastures or brush grown places where such trees and shrubs as I have mentioned abound and afford the necessary support and concealment which are invariably. sought, in such places also they secure their prey, and their young çan climb about in comparative safety until ready for flight.

The swift of North America has been often cited as a remarkable example of a bird which has changed its nesting habits in recent times. Formerly breeding in hollow trees, and still doing so in remote places. it now regularly resorts to the abodes of man and glues its wicker nests (see fig 8, part I) to the inside of chimneys. Both the barn and eaves swallows, and indeed many other species are in like case, but we cannot accept the riew that the halits of any of these birds have essentially changed since the advent of white men to this continent three hundred years ago. The swift indeed, shows a remarkable uniformity and precision in its instincts which have remained unaffected by the presence of man, the boasted change referring merely to the position of the nest in artificial as distinguished from natural structures. These birds, like hundreds of others, come to the clearings and to towns for their food, and like them also, merely adapt the altered physical conditions to their establisher needs. Like the stork nesting on the housetop, or the osprey on the cart wheel set horizontally on a high pole, or indeed the purple martin or the bluebird, which take kindly to the house provided 
for their exclusive use, they simply go where food abounds, and when not deterred by fear, fraternize with man to some extent.

The swift inherits the tendency to nest in a dark and cavernous place with free entrance and exit, and to its mind the chimney is a hollow tree with better ventilation in summer, but with poorer protection from rain than that which the forest supplies; but so far as the immediate environment goes its instinct is not quite precise or uniform, for the interior of a barn or of any dimly lighted building, where no interference is offered, may be chosen upon occasion. To conclude, so far as nesting and general habits go both swift and eaves swallow are remarkably constant, and far more so than either the robin or the song sparrow.

Certain phases of the question of position, especially in reference to the immediate environment will be considered at this point.

Uniformity in the selection of nesting site. That certain birds or their young, as in the case of the flicker or redheaded woodpecker, often return to the same nest site,- - to the ancestral tree, bird house or box, - is adequately accounted for on the principle of association, and the proved tendency of the young to return to the place of birth. On the other hand certain species of birds, like the orioles and vireos choose their nesting sites with great uniformity; in our own minds we invariably associate the Baltimore oriole with the elm, the red-eyed vireo with maples, sapling pines with black-billed cuckoos, and tall evergreens with crows and many of the hawks. As in the other cases considered so far as the birds are concerned, the association is primarily due to the supports furnished by such trees in relation to the food and the habits of the species in question. The problem is precisely the same as in the robin, but with the field of choice greatly restricted. While I have seen hundreds of robins' nests in the apple, maple and elm trees, the number found in the poplar (Populus tremuloides), and gray birch (Betula alba) during a period of over twenty years, is not more than one or two in each instance, a fact which we should attribute to the lack of proper supports which they furnish, when the requirements of cover and other needs are completely met The building robin makes an equally good choice, as we have seen, whether it takes to the pine, maple, apple, or oak, but the response of 
the red-eyed vireo (see fig. 9) is limited to a much narrower range: its support must be a forked twig of not greater diameter than a lead pencil, and this fork must be fairly stiff, horizontal and of suitable angle: the various maples, whether as saplings or as larger trees, and the witch hazel in less degree furnish these conditions to perfection, while the pines seldom or never do; the former are consequently chosen wherever food abounds. The vertical height at which such a nest is placed is a matter of secondary importance from the standpoint of the bird, within the limits set by the whole trend of the habits of the species.

A long series of experiments on moving the nests of birds together with their supports, which are tabulated in an earlier work already referred to (see note No 6, p. I6I of part I), illustrates a slightly different phase of the question. For a brief period the element of association appears to be sifted from the instincts, when a bluebird or cedar waxwing will immediately fly to the point in space formerly occupied by the nest, and hover there for a moment, following the old course which habit had marked out. This may be repeated several times and for the space of twenty minutes more or less, or until the young are heard or seen in their new position. When, however, these young are once found and visited the old habit is quickly lost, and a new one formed.

Do birds in nesting seek the protection of man? To follow the problem of position of the nest into another quarter, Nuttall 22 has remarked that the robin, in order to secure protection from its numerous enemies " has been known to build his nest within a few yards of the blacksmith's anvil; and in Portsmouth, New Hampshire, one was seen to employ for the same purpose the stern timbers of an unfinished vessel, in which the carpenters were constantly at work, the bird appearing by this adventurous association as if conscious of the protection of so singular and bold a situation." It is a pity to take all the poetry out of such agreeable suggestions, but in most cases at least the truth certainly lies in another direction.

Audubon ${ }^{23}$ again speaks of finding a nest of the robin fastened

${ }^{22}$ Nuttall, Thomas. Ornithology of Eastern North America, vol. 1, p. 200, Boston, 1897. 1834 .

${ }^{23}$ Audubon, John James. Ornithological Biography, vol. ii, p. 192 Edinburgh. 
to the cribbing timbers of an unfinished well seven or eight feet below the surface, and of another which rested on a bare ruck. It would surely be interesting to know whether the habit of nesting low, implied in these and similar cases which could be given would outlast the season, but on this point we can offer nothing at present.

The evidence that certain individual robins, swallows, or bluebirds seek the neighborhood of man or noisy situations for the protection thus secured, is probably delusive. As we have said, they come to places inhabited by man chiefly for food, and that they learn to endure noise and disturbance through association is not to be doubted. The protection thus gained is incidental, and wherever the domestic cat reigns it can be but slight at best. and certainly not greater than in a more primitive environment In any case we should need to know the conditions under which the nest was started, for a robin or bluebird will begin to build about machinery or on the timbers of an unfinished dwelling when the workmen are away, with perhaps a quiet Sunday intervening, and then by instinct and by association hold to the chosen spot in spite of all ordinary obstacles. Many cases are constantly reported in which birds have chosen the most extraordinary and anomalous positions for their nests, the choice being possibly made under the conditions intimated. The following account will illustrate the class of nests to which I refer

A bluebird's nest was discovered by workmen near my home in Cleveland Heights Village, Ohio, while engaged in taking down the framework of a sewer trench, on May 19, I910, at this time it contained three young nearly able to fly. This singular nest was placed in a narrow pocket of the framing, and but a few feet from an overhead track, on which for weeks a line of suspended dumping cars had been running back and forth during working hours, and with what noise and jarring can be easily understood, for over a month besides it had been subjected to repeated danger from dynamite blasts which showered stones all about it from the trench below; meantime with the advancing work of construction it had travelled along the street for about the distance of a city block. and all the time close to the grinding racket of a steam engine with its screeching whistle, and to the laborers who, in operating their cars, passed directly under it. 
Who would say that such untoward surroundings were deliberately sought for the protection afforded by man" In this instance a most unfavorable site was without doubt chosen on account of the support and apparent protection suggested by the dimly lighted hole in the frame, while quiet reigned and when man was absent from the scene, and then held to by instinct and association, in spite of drawbacks however formidable. Attachment to the chosen site is instinctive and increases hourly, while it is also strengthened through association, which may come in time to rob every kind of noise and disturbance of its terrors. While the ascending curve of attachment, heightened by the guarding instinct, rises rapidly, the curve of fear is correspondingly depressed The question is first a specific, and then an individual problem. The upward curve ascends more rapidly, it may be, in bluebird than in cedar waxwing, but again this ascent may be steeper in one bluebird than in another. more abrupt in a town rubin than in one born and bred in the wonds The last court of appeal in such a case will always be the experience of the individual, and the mutual reactions of the pair

On the contrary I would not affirm that the robin's nest which $I$ have seen built on the stringers of a railroad bridge, but a short distance below the level of the rails was built during a long interval of quiet. The interval required may in certain cases indeed be very short, and its necessary length will depend again upon the history and instincts of the mated pair. Of all such experiments which are tried by birds we may be sure that many fail.

Individual change in nest site. While many individual eagles, hawks, robins or sparrows which habitually nest aloft or at at certain height from the ground, occasionally come to the earth, while others like the herring gulls and mallard ducks which as commonly build upon the ground will sporadically ascend and place their nests in trees and often at a considerable height. To attribute such actions to the lessons of experience, as has often been done, is quite as justifiable in one case as in the nther. Such conclusions seem to be rather gratuitous, and lacking in the proper kind of supporting evidence. We do not rule experience out of the problem of beharior at this point, but are conrinced that most of such minor individual changes are due tr other causes. 
Audubon's ${ }^{24}$ remarks on the herring gulls on White Head Island at the entrance to the Bay of Fundy, have often been noticed. At the time of his visit, on May 22, 1833 , he was surprised to see their " nests placed on branches, some near the top, others about the middle or on the lower parts of the trees, while at the same time there were many on the ground." To Audubon the owner of the island declared that the habit of nesting in trees had been acquired within his own recollection, for he said, "when I first came here, many years ago, they all built their nests on the moss and in open ground; but as my sons and the fishermen collected most of their eggs for winter use, and sadly annoyed the poor things, the old ones gradually began to put their nests on the trees in the thickest part of the woods. The younger birds, however, still have some on the ground, and the whole are becoming less wild since I have forbidden strangers to rob their nests."

The conclusion thus drawn in regard to the cause of the change in habits observed, is not strengthened by the further statement of Audubon that "on some of the islands not far distant, to which the fishermen and eggers have free access, these gulls breed altogether on the trees, even when their eggs and young are regularly removed every year," and that "the young on the trees are shaken out of their nests, or knocked down with poles, their flesh being considered very good by the fishermen and eggers, who collect and salt them for winter provision." Some of these birds nested as high as forty feet or more, and Audubon predicted that after further molestation they would go still higher, and finally build in security in the rocky shelters on the summits of some of the islands, as a few had been reported to have done already.

If the variation in nesting habit noticed above were the result of intelligence, we should expect that the birds would take a further step and abandon their island altogether when the limits of persecution had been reached. But this logical step seems to be never or but seldom taken, as shown by the history of the Hebrides and other rocky islands to the north of Scotland and Ireland, of Ailsa Craig, or of Bird Rock. Indeed there are few rock pinnacles or ledges which the intrepid eggers cannot reach, and in some places as at St. Kilda, they have plied their trade

${ }^{2 *}$ Op. cit., vol iii, p. 588 . Edinburgh, 1835. 
for ages, with the aid of ingenious snares, poles and ropes. Yet true to the instincts and traditions of their race the many kinds of sea fowl, though regularly robbed, resort each year to their rugged homes to breed. We are reminded of the compass like precision with which many birds keep to the fatal overland and coast routes in Italy and other parts of the Mediterranean, which they have followed for ages, in spite of the terrible persecution which has awaited them each year, not to speak of other migration routes over sea. which at the time of their origin, for all we know to the contrary, were really over land. Fortunately some of these wonderful bird colonies, which now represent but the remnant of the hosts of an earlier day, are being wisely preserved.

My own experience with the herring gulls has been gathered from studies of the two largest communities on the New England coast, at the Duck Islands, Maine, which lie from five to seven miles to the south and east of Mount Desert. Both islands are partially wooded, but the lesser to the north is occupied only by semi-feral sheep and still wilder sea fowl, it supports the larger community of gulls, the nests of which are scatered over the rough bush grown slope of its southern side. The birds of this community have never been strictly protected, and though shy and difficult of approach, they have never taken extensively to breeding in trees so far as known.

On Great Duck there is a fine colony of upwards of 4,000 birds which occupy a more restricted area of high rocky shore and fallen spruce woods, now largely clear, especially in the vicinity of the Government Lighthouse, at its extreme southern end. Though shamefully persecuted from the days of the Indian on both of the islands, the colony of Great Duck was taken more especially under the protective shield of the Audubon Society about twelve years ago. Its nests are more concentrated, and its members less shy than on the smaller domain, but so far as I have been able to learn the habits of both communities have remained essentially the same from an early day. At either point comparatively few birds have taken to building tree nests. To have formerly disturbed them by firing a gun, or by a succession of dynamite blasts as I had occasion more recently to observe, was to throw a large part of the com- 
munity into panic, when they would ascend to a great height, or leave the island until peace was restored.

In any event, building their nests in trees, as a few now do at a common height of from six to ten feet, could have afforded them no protection from man, and probably none from their one other inveterate enemy, without their own ranks, the crow, which still harries their nurseries at will.

A census of 100 nests of this gull, taken at random, was made on the island July 17,1902 , and in regard to position gave the following results:

\begin{tabular}{llllr} 
Ground nests, of ten placed under dead spruce & & $\ldots$ & 89 \\
Tree nests in upright spruce, either living or dead, i to 9 feet &. & 6 \\
Rock nests, on ledges, and usually nearer the seat &. & $\cdot$ & 2 \\
Nests on logs or fallen trees &. &. & & $\frac{3}{3}$ \\
\hline
\end{tabular}

Had this survey becn made on the confines of the colony the number of nests placed on bare rocks would have been greater, but so far as trees are concerned the results would have been essentially the same

In relation to tree nesting another question must be considered, and that is the restrictions imposed upon the young, especially when their nests are at a considerable height. As I have shown in an earlier paper ${ }^{25}$ the gull community is organized on a peculiar hasis, and this is particularly important in such crowded communities as found at Great Duch. Each pair of birds discriminates their own chicks with precision, and guards the territory or preserve on which are placed their nest, cover for the voung, perches and feeding spots, with the utmost vigilance Trespassing adults are fought off, and straying chicks are quickly struck down and often killed in cold blood, unless protected by their parents. The admirable guarding instinct is thus the cause of many untimely deaths in every community, and numbers of recently slain birds of all sizes can be seen any day upon the breeding grounds Now nesting in trees would undoubtedly tend to check the errors of instinct in permitting the too early or too indiscriminate straying of the young, and thus be a source of protection. Without any doubt young are liable to fall out of the nests when close to the ground, but at

\footnotetext{
${ }^{25}$ Organization of the Gull Community. Proceedings of the Seventh International Zoological Congress. C'ambridge, 1909.
} 
a height of from ro to 40 feet they would be likely to remain until ready for flight, as Audubon remarked The tree nests, as this excellent field naturalist also noticed, are considerably greater in circumference than those built on the ground. and this fact tends to greater security from accidents, while it affords the chicks more ample room for exercise. On the whole tree nests undoubtedly favor the gull chick, but they do not favor the parent directly for it must bring more food to satisfy the hunger of its young; eridently there can be no foraging for insects, a privilege enjoyed by all birds reared upon the ground, for many weeks, before they take to the water and are ready for flight

Upon the strength of all the facts at hand we are bound to conclude that individual variation in the position of the nest for the gull, has no immediate reference to protection from man or from its few common enemies; it may favor the young under certain conditions, but the variation is often of too slight a character to have any significance. This was particularly well illustrated in an allied species at one of the little Weepecket Islands, in Buzzard's Bay. Massachusetts, where in July, Igoz I found a single nest of the roseate tern, raised two or three feet above the level of the rocks and sand and fixed between upright culms of sedge, a variation in building habit the more striking since all the other nests were upon the ground. Here again the variation could not be attributed tn protection either sought or gained, since it was the most conspicuous nest of the little colony.

Many cases could be given of novel, difficult or eren fatal nest sites being adopted by rarious birds, and in the first instance repeatedly chosen. regardless of the teachings of experience A good illustration of the latter is seen in the stupid persistence of the eaves swallow or house martin (Hirundo urbica), as described by Gilbert White. ${ }^{26}$ "Birds in general " says the naturalist of Selborne, "are wise in their choice of situation. but in this neighborhond every summer is seen strong proof to the contrary at a house without eaves in an exposed district, where some martins build year by year in the corners of the windows. But as the corners of these windows (which face to the south-east and south-west) are too shallow, the nests are

${ }^{20}$ Natural History and Antiquities of Selborne. London, 1883, p. 137. 
washed down every hard rain; and yet these birds drudge on to no purpose from summer to summer, without changing their aspect or house. It is a piteous sight to see them labouring when half their nest is washed away, and bringing dirt 'to patch the ruins of a fallen race." "

The American robin, to cite another instance, has been found nesting in the drooping slender branches of the weeping willow, and in an osage orange bush, ${ }^{27}$ where the mother was found impaled on one of its thorns. Such instances are wholly exceptional, but it cannot be confidently asserted that they are always the result of youth or inexperience.

It appears to be equally futile to attribute the act of occasionally nesting on the ground on the part of any species which habitually goes higher to the needs of protection as the result of experience; all such nests are very unsafe, and birds like the song sparrow which frequently indulge in the practise, are apt to lose their broods when the sitter is not wiped out in the bargain. About the only way I can be sure to preserve such nests when found, is to fence the whole with a fine wire screen. To conclude, the golden eagle which is limited to no narrow range, and can take care of itself under most circumstances, commonly selects a lofty tree where its huge nest stands i out like a castle on a hill, or a rocky hill top or precipitous cliff ${ }^{1} \mathrm{n}$ the mountains or by the sea, but on occasion, when possibly induced by the greater accessibility of food, it has been known to rear its home in far humbler surroundings, on the treeless plain.

Size of the nest. The size and weight of individual nests are subject to greatest variation in those of the statant type, a fact dependent mainly upon the nature of the site and immediate support. Thus when other conditions are approximately uniform we should expect to find robins' nests, built upon flat shelves and protected from the weather, to vary far less in these respects than when placed in crotches or upon inclined branches of trees. The bluebird and house wren which commonly adapt natural and often contracted cavities to their needs, usually carry in little building material, and this is molded to form a scant lining, but when coming to a box or bird house they will fill the whole space before modelling an inner nest wall at the farther end for immediate use. Under such conditions the

\footnotetext{
${ }^{27}$ Dawson and Jones. The Birds of Ohio. Columbus, 1903, vol. i, p. 224.
} 
amount of material may be ten times greater than is commonly used, and such proceedings undoubtedly render them safer from the annoyances of other birds. It appears like a measure to secure protection; at any rate it is an adaptation to surrounding conditions.

Whenever a bird of this group (see table II, of part II, No 3 , i. b.) makes a nest of odd or irregular form, it would be well to carefully examine the site, to which it may be merely a clumsy adaptation, and to note in particular the size and character of its inner wall, before hastily inferring that the bird was blundering in the dark, through inexperience, or the loss of its " copy" book," so to speak The variation may prove to be unimportant, the inner wall (character No. I of the analysis given above) conforming strictly to the specific type.

The size and "perfection " of the nest is subject to a number of variables (see p. 177 of part I), some of which are hard to determine. When the first egg is laid before the nest is completed, the building instinct is liable to subside, and a somewhat scamped or imperfect nest to result. Echoes of this instinct, however, are sometimes perceived many days after the eggs have appeared and incubation is well advanced. Thus the great herring gulls are likely to add fresh materials to their nests at any time, and I have seen this bird while brooding her eggs, reach down with her bill, pull a little fresh grass by the roots and drop it on the nest wall or tuck it underneath her body: the white-bellied martin will return feathers which have blown from its box, even after its young are fledged, and both eagles and hawks occasionally bring a fresh spray of evergreen or seaweed to their eyries, but we should not be justified in referring such acts to the building impulse, without a knowledge of all the factors which mold conduct at other times and under other conditions. Thus the gulls are constantly pulling and carrying about what looks like nesting material, whether they are building a nest or not, and whatever the condition of their eggs or young.

A case has indeed been recorded in which the walls of a hummingbird's nest were gradually raised from the time the eggs were laid until the young were fledged, when the structure had grown to more than twice its original size. The behavior of the gull just noticed should throw some light on such acts, and 
the inference that measures of this sort are adopted to save the young from falling out of the nest receives no support.

Compound or superimposed nests. We have been considering simple, individual nests, but have earlier referred to aggregated nests, or those composed of closely associated units, such as are made by the sociable grosbeaks (see p. 184 of part I), or the waxwing (Dulus dominicus) of San Domingo, as well as to compound nests representing a more or less extended series of "supra " or "infraimposed" structures, as in certain gulls, eagles, doves, warblers, vireos and weaver birds, whenever an old nest, whether of the same or of different individuals or species is used more or less completely as the site of a new one. Under such conditions the greatest variation in size and weight may be expected.

In illustration of the foregoing remarks, compare the first season's nest of a robin, with the same when used for a second brood, the nest of a herring gull " repaired," and occupied the following year, as was reported by Audubon is and has been noticed by others since, the eyries of the eagle and fish hawk, which are occupied for successive years, and which vary in height in proportion to their age, within the limits of stable equilibrium. This increase is to be observed in the white headed eagle under certain conditions, but would not hold where the nest was diminished through the process of natural decay. The greatest recorded period during which a given nest and nest site has been continuously occupied, is considerably over the century mark. Thus, according to Newton, an eyric of the falcon (Falco peregrinus) on Arasaxa, a hill in Finland, was in continuous use for I I 9 years ( $1735-1855)$, and an earthenware bottle or its substitutes, in the branches of a tree in a garden at Oxbridge, England, was known to have been used by the blue tit (Parus corrulens) from 1779 to $\mathrm{r} 888$. We have finally to notice the remarkable "storied," or serially superimposed nests which a yellow warbler or vireo will sometimes build, whenever their breeding cycle has been repeatedly broken by fear, and the site of the old nest is successively chosen as that of a new one. ${ }^{20}$ In this way, as we have shown, the parasite's eggs are admirably "concealed," and its designs frustrated.

\footnotetext{
${ }^{28}$ Op cit., vol. iii, p. 590.

${ }^{29}$ For illustrations and fuller discussion see Instinct and Intelligence in Birds. Popular Science Monthly. New York, 1910, vol. Ixxvii, p. 87-92.
} 
The remarkable pendent nest of the Indian weaver bird (Ploceus baya) consists of a grass lined globular chamber which is suspended to a branch by a long fibrous cord and extended below in a regular, woven tube which serves as entrance. Such a nest may be used for successive years when it becomes compound by the addition of new chambers below the last in succession, until in one case recorded there were seven "stories," the last of which, being made of fresh grass, probably represented the nest of the current year; yet three of the lowest chambers, if not in actual use, at least contained eggs. Such " infraimposed" structures are clearly comparable to the compound nests of the fishhawk and eagle or even of the vellow warbler already considered.

"Double" or "triple" nests placed side by side, and more or less completely joined, are rarely reported (for a beautiful illustration of a double nest of the red-eyed vireo, contaning one and two eggs respectively and both male and female siiting when discovered, see Dawson and Jones "Birds of Ohio," vol. I, p 296); they may be due to one of several causes, but when containing eggs probably result from a disturbance of a first cycle usually after a single egg has been laid, and the building of a new nest beside. rather than on, the first. Such rare chances for observation should not be lost by disturbing the nests, and I think it will be found that the female completely abandons the first, and that the ardor of the male in reference to it soon dies down.

The materials of nests and their method of arrangement. The kinds of material used by birds in the construction of their homes has been detailed at great length; indeed it is under this head (No. 4 of analysis given above), as well as on the method of arrangement and dimensions of the walls that the literature of nests is most complete. The inferences which have been drawn from their use of materials are not so satisfactory.

The question of the kinds of material used by birds in nest building is not very important when we consider the majority of makers of increment nests. Yet there is a considerable number of species which are wonderfully uniform in both their choice and treatment of building materials. Between the extremes every intermediate degree is to be noted On the one hand 
they take from their immediate enrironment whatever they can use in adaptation to their needs and methods of work, while on the other they will go long distances in search of what they need or prefer, such as soft mud, spiders' silk, hair, fine vegetable substances, or even the cast skins of snakes, yet many in this case are often quick to adapt materials nearer at hand to their immediate use. The endless variations to be noticed in such particulars, while the source of much popular interest, are usually not important, because of their inconstancy. While the external form and appearance of the nest may vary considerably under such circumstances, it is safe to say that the building materials, however bizarre or incorrigible, receive the samr kind of treatment, and that the inner wall is not essentially changed. Accordingly any marked variations in nests of this sort are due to accident, so far as their builders are concerned, or to the environment, rather than to any important change of instinct or habit.

The rule of coarser materials first and finer or more pliable last is seldom departed from, especially in all such as build an increment nest, of the upright standing form, and neatly mold an inner wall, though in some cases, to be sure, the nest is very uniform throughout, whether exceedingly soft as in the ruby throat (fig. 18), the goldfinch and yellow warbler, or when made entirely of the culms of grasses or of coarser twigs. Yet I have even found the soft nestling down feathers of some wild bird to enter more completely into the lining of the hummer's nest than in any part of its outer walls.

If we were to confine our attention to certain species of birds such as the osprey (Pandion haliaetus carolinensis), and hooded crow (Corius cornix) we should have to admit that no junk dealer could present a more motley array of articles drawn from every kingdom of nature as well as from the arts and devices of man than the nests of these birds on occasion afford. ${ }^{30}$ An old broom and rake, a rag doll and toy sail boat, an old door mat, shoe brush and feather duster, egg-strings of the common conch, and coils of rope twenty feet long, tin cans as well as sea shells, bright stones, and the bleached bones of cattle, not to speak of a new hat blown from the head of an unfor-

\footnotetext{
${ }^{30}$ The following notes are drawn from "Breeding Habits of the Fish Hawk on Plum Island, New York," by Charles Glover Allen. See The Auk. New York, 1892 , vol. ix, p 313-321.
} 
tunate passenger on one of the Fall River boats, and seen in the talons of the hawk when under way to its nest, all come as perfectly to the hand of this beach comber, as the store of soda bottle wires picked up in a back yard, or the entire stock of steel spectacle frames, stolen from an optician's window in Calcutta or Bombay, suits the tastes of the unconventionial crow, or indeed as the five or six green leaves or as many pebbles, at times satisfies the simpler tastes of the arctic tern at Matinicus Rock, Maine.

Again were we to examine a series of nests of either the ruby throated humming bird, the red eyed vireo, the Baltimore oriole, or even of the robin we should have to admit that the range of choice in the selection of materials had been narrowed greatly with correspondingly greater uniformity in their treatment Indeed we approach more nearly the wonderful uniformity displayed by the mud and paper nests of wasps, and the prismatic wax cells of the honey bee, an unmistakable index of the more complete sway of instinct in guiding the actions of the builders. We might add that the crow and his tribe, which are generally regarded as the most intelligent of birds, can seldom be trusted in the presence of any bright or shining objects whatsoever which they will carry off and either hide or work into their nests.

The nest of the common robin forms as good a text as any from which to view this subject, and we shall later see how it is built. Probably in not one nest in a thousand, examined by interested persons, have the conditions under which it was built been accurately known; yet it is these conditions, such as the state of the weather, the nature of the site, and the character of the general environment, not to speak of the synchronization of the instincts, which mainly determine the character of such nests; the more uniform the conditions the more stereotyped the result. Upon a foundation of dead weeds and stubble this bird usually raises a clay cup; the softened mud and other materials are well incorporated to form a consistent mortar, and a lining of finer grass is usually added. Now either a lack of suitable materials, as in times of drought, or of the proper instinct causes some robins to dispense with the mud cup, while prolonged rains hamper all which build in exposed situations, and melt down their walls as fast as they can raise them. Where 
mud is essentially lacking in a finished nest, a deep foundation and thick wall of dead grass and stubble is commonly found. All that we can say at present is that while mud is regularly used in a peculiar way and with a definite result, it is sometimes wanting, the only earth present being that which incidentally clings to the roots of stubble pulled from the ground.

I have a robin's nest taken from the spruce roods on Great Duck Island, Maine, which is composed wholly of coarse spruce twigs, black peat, and a lining of withered grass blades, materials which were available in the immediate vicinity of the nest. It is the only specimen which I have seen built so largely of coarse stiff twigs, but the dimensions of the inner wall, and the treatment which the material received are typical. The variation was evidently a response to the immediate environment, and is unimportant Nuttall speaks of a nest of this bird, "bottomed" with a mass of pine shavings taken from a carpenter's bench, a variation similar to that mentioned above. Again if given strings or streamers of colored yarn, though white is preferred, robins often take them eagerly and work them more or less effectively into their nests. I have even seen a pocket handkerchief which a robin picked from a line or from the ground and carried into a tree, where, however, it was caught so that the bird failed to use it.

The fact that the robin brings plastic earth to its nest in two ways, incidentally in the damp soil clinging to the roots of pulled grass or stubble, and directly in large lumps of barely consistent mud, and that all is treated in a fairly definite manner to mold a symmetrical cup is a highly interesting fact, for it suggests the origin of the direct use of mud in all such building uperations. A more durable and better nest resulting from the casual use of plastic earth thus accidentally introduced at an carly stage of the proceedings may have furnished, on the principle of selection and other possible factors of evolution, the starting point for what in the course of ages became a fixed and settled custom. ${ }^{31}$ The fact also that its near ally, the blackbird of Europe (Merula atra), builds in precisely the same style, not only suggests the high antiquity of the practise, but illus-

\footnotetext{
${ }^{31}$ It should be added that in exposed situations and when subject to drenching rains the mud cup is distinctly disadvantageous, since without drainage below, the nest is liable to eatch and hold too much water.
} 
trates the fixity of such an instinct when definitely established and correlated with other actions. The robin does not inherit the instinct to use mud in nest-building, any more than it inherits the tendency to use weeds, sticks or grass, or the hummingbird, lichens, but it is born endowed with tools and with tendencies to use them in a more or less definite manner upon plastic and other materials drawn from its environment, although in this bird certain kinds of material more readily awaken its building responses than others.

In describing a series of nests of the English merle or Wackbird Rennie ${ }^{3:}$ remarks that the outer framework differs but little from that of the song thrush (Turdus musicus), or mavis, " except in being more massive, as is also the clay lining, which is put on in a very wet state, probably to save the saliva of the bird, but to prevent this moisture from injuring the eggs, it is lined with a thick bedding of dry hay, which in some nests is very neatly worked into the hollow formed by the clay, while in others it is laid less skillfully, and hence the nest is rendered very shallow. In two of the nests in my possession the masonry of the clay is carried around the branch of the bush where they were built, in order to make it fast. which circumstance, as it is not of usual occurrence, shows that the little architect was guided by intelligence akin to rationality, if not identical with it. and not by what is usually called blind instinct "We give this description for the sake of comparisons with the American robin; in our bird the lining is sometimes of green, not dead or dry grass, and is sometimes dispensed with altogether; the lining in all probability has nothing to do with moisture, and though it forms a softer bed for the eggs it is of ten so slight in the robin as to suggest that it may be only the relic of a period when such nests were built without the aid of the mud cup at all.

The clay cup of the robin also suggests an interesting variation in a nest of the olive-backed or Swainson's thrush in my possession, ${ }^{33}$ and at the same time illustrates the importance of the study of behavior, as a check to the interpretations of structure. Of the tro nests of this species, which I have to describe, one was from a pasture, the other from a peat swamp. Let

${ }^{32} \mathrm{Op}$ cit., p. 131 .

${ }^{33}$ I am indebted to Miss Cordelia J. Stanwood of Ellsworth, Maine, for this as well as for many other rare or interesting nests which she has collected in the course of her studies of the bird-life of that region. 
us see how the immediate environment has apparently affected the work of the builders in each case. The first is typical of this bird, and was built in a fir tree at a height of five feet from the ground. It is rather bulky, though smaller than a robin's, standing $3 \frac{1}{2}$ inches, when removed from its support. The cup is well modelled, and measures 2 inches deep by $2 \frac{1}{2}$ inches across at the brim. Though the walls reach a thickness of two inches. being rather loosely compacted of vegetable matter only, the whole is very light, weighing barely an ounce. Fine fir twigs, rather fine dry grasses and rootlets, interspersed with Polytrichum and other mosses constitute most of the building materials, the cup being lined with the skeletonized leaves of a wild cherry and a jet black regetable fiber suggesting horse hair. and probably representing setae of one of the mosses.

The other nest, though thinner in construction weighs more, and appears to have an earthen cup, fairly well modelled and compacted, like a robin's It was found in a peaty meadow, and was taken when the young left it on July I2, so that its lining has been more or less pulverized through use. The suggestion that this bird has adopted the robin's peculiar methods, however, is quickly dissipated, when we examine it more closely, remember the environment, and the probable habit of using moss in this species as the robin pulls stubble, and the amount of damp earth liable under certain conditions to be taken to the nest in consequence. The cup of this thrush's nest is not strictly a "mud cup" at all, but appears to be formed of the stalks and rhizoids of mosses pulled by the bird from the peaty swamp, and of the black earth and sand thus casually obtained; this was later subjected to the molding movements of the bird in the usual manner, and was further compacted by the weather and the actirities of the nestlings. Though such a nest presents a very unusual appearance, if this interpretation is correct, it is normal in every respect.

Miss Stanwood, who has examined over thirty nests of the Swainson or olive backed thrush, writes that they all have the bulk and general appearance of the robin's, and are conspicuously placed in bushes or low trees. As many as thirty kinds of vegetable materials sometimes enter into their loose outer wall, while a thick inner layer of dead wood, which seems to correspond to the mud cup of the robin is usually present and 
is held in place by masses of fine rootlets; the lining proper, which always shows some skeletonized leaves, is of usnea lichen, green moss or fine black vegetable fibres of some sort.

In marked contrast to most builders of increment nests already referred to, which appropriate all kinds of objects regardless of their form, color, or origin, and mold them in some fashion to their use, stands the stereotyped performance of many mud

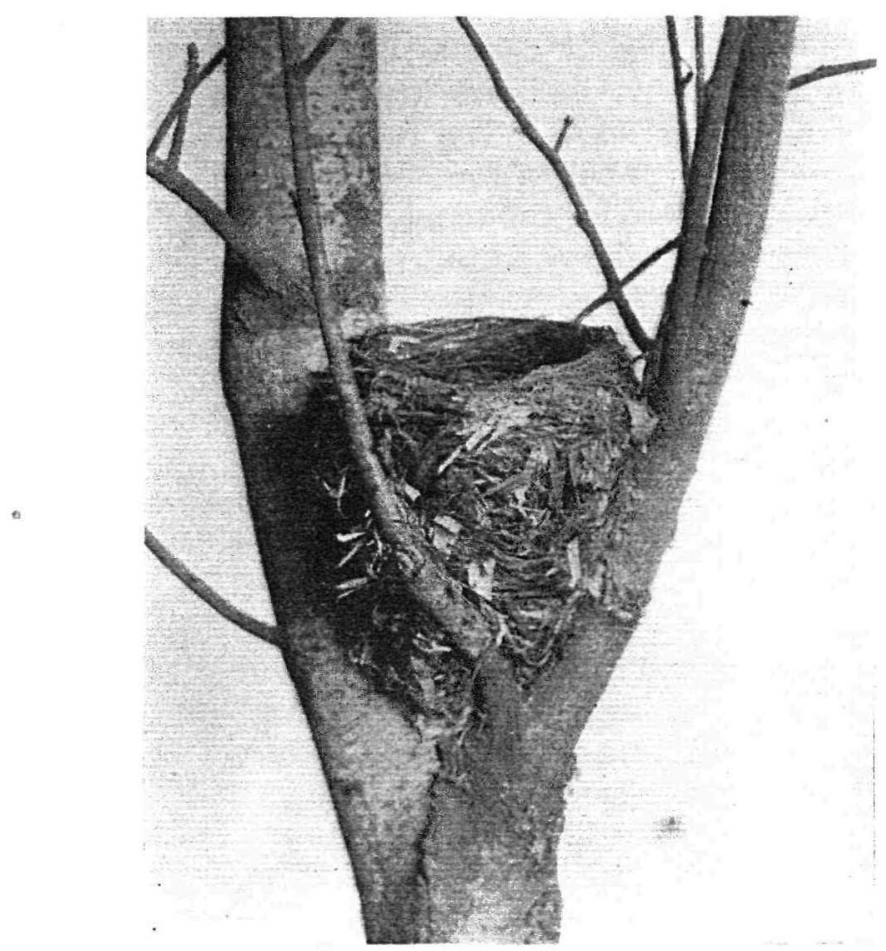

FIGUn: 11-Nest of the American redstart (Setophaga ruticilla) illustrating perfect modelling and symmetry of cup, in simple adaptation to support. Diameter of cup, $43 \mathrm{~mm}$. (111 inches): depth cup, $35 \mathrm{~mm}$. ( $1 \frac{3}{3}$ inches): diameter nest

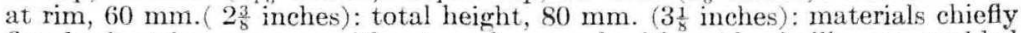
fine bark strips, coarser without, and secured with spiders' silk: cup molded out of the blades and stems of very fine grass: in gray birch, 12 feet up. Ellsworth, Maine.

plasterers like the eaves swallows and oven bird of South America, or of saliva workers, such as the swifts. The nests of the esculent swiftlet (see fig. 7, part I) are compacted of hardened saliva only, and are highly uniform in size and shape, while the 
common chimney swift in building (see fig. 8) uses only slender dead and brittle twigs, which are snapped off on the wing: they are further glued to their support and to one another by means of viscous saliva, and with the uniformity of a basket weaver's art. (For example of nest showing greater variation in materials, but perfect in type see fig i I )

Appropriation of nest materials illustrated. While certain birds, as we have seen, go far at times to find suitable nest materials. and make use of definite kinds. the majority take from their immediate environment only, and adapt whaterer it has $t o$ offer to their needs. The robin in nesting time may be seen flying high with ball of mud in bill, having travelled a quarter of a mile or more for the requisite substance, but it does not follow that under like conditions all would do the same: their conduct, as we have shown, will depend upon a number of variable factors, but the rule in this instance is to take what crimes nearest to hand.

The great herring gulls of the Duck Islands probably travel at least thirty miles in search of food, but in building their nests they draw only upon the resources of their island, and mainly from at areat of very short radius; again I have known certain arctic terns on Matinicus Rock to gather everything used in building their nest within the compass of a square yard, or even to limit themselves to the leaves and pebbles within reach of bill, while sitting on the chosen site. The ospreys on Plum Island, on the other hand. were formerly known upon occasion to levy tribute from a distant shore.

The appropriation of nesting materials from the nearest source was well illustrated by red eyed vireos and cedar waxwings in central New Hampshire Now it is the practise of these rireos to line their nests either with fine bark strippings or with old needles of the white pine where both abound, but in other parts with bast alone The question arises whether the species is split up into certain gens, one favoring this and another that matcrial, or is it a case of individual preference, dependent upon the environment mainly; we cannot answer definitely, but are inclined to the latter view A nest of this vireo referred to (No 2, table 3), was built in a maple tree, close to a dwelling house; the frame of this nest was made entirely of grape rine bark, the finest strippings being worked into the inner wall. 
One rod distant from the tree stood a number of white pines, and their withered needles littered the ground all about, while at thrice this distance in another direction a grape climbed into an apple tree. It is possible that discovery of the rine in the first instance immediately awakened in this individual the building responses, and decided in faror of the bast, at least the case of the cedlar waxwing, which is typical of many others.

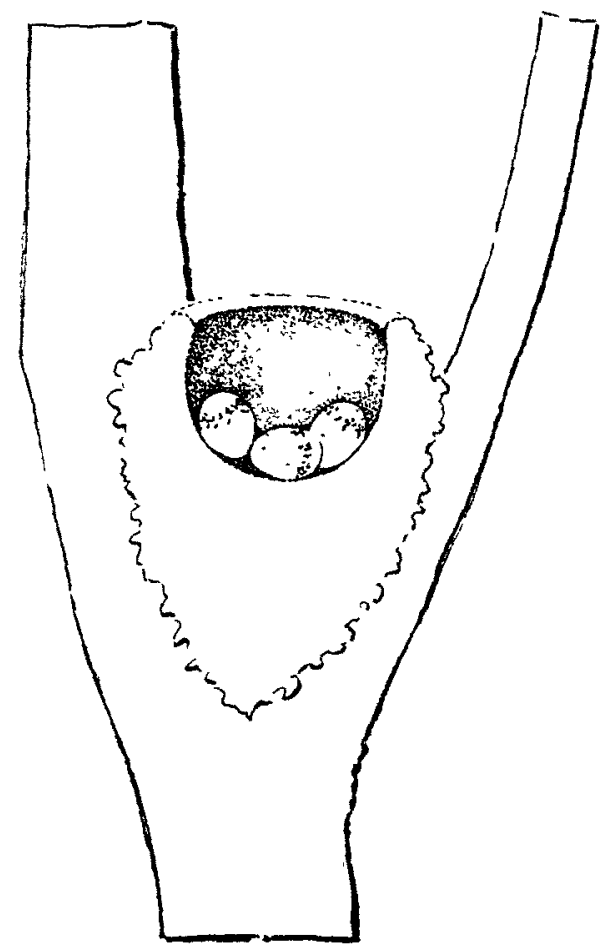

Fiture 12-Sectional view of nest shown in figure 11 and drawn to the same scale, to show form and symmetry of cup, and relation of entire nest to support

points to this conclusion. In nests of the vireo from northern Ohio, where the white pine is but rarely if ever found growing under natural conditions (compare nest No. 3. table III) the bast habit seems to prevail.

In line with the maple referred to above stands a larch, in which a cedar bird built a neat nest, this was wholly framel of the dead brittle twigs of the tree and lined with pine needles, all having been evidently gathered from the ground below. 
Further, in an orchard on the opposite side of the house, but less than five rods from this point, another waxwing built a grass nest and used as lining the fluffy heads of the low cudweed, patches of which were growing on the hillside close at hand. Without splitting words on the subject of "choice" in such selections, it is evident that a great variety of natural products awaken certain responses concerned with the complex acts exhibited in building the nest, and awaken them promptly in all such birds.

We have already spoken of the general methods of arranging the materials used in building ( $\mathrm{No}_{3}$ of the analysis given above), and are now ready to consider the most constant characters of nests (Nos. I and 2), the form and dimensions of the inner wall, and the treatment of the outer surface when characteristic To repeat, we find the characters of the inner cup, and of the outer surface when subjected to peculiar methods of molding, smoothing, or incrustation, the most constant characters of increment nests, because due to instinctive activities of uniform type. The amount and nature of the substances employed are as a rule quite subordinate to the methods of work. When the outer wall does not undergo a peculiar smoothing or garnishing process the nature of this surface is subject to greater variation and is consequently unimportant.

\section{VARIATIONS IN THE NESTS OF CERTAIN BIRDS}

The uniformity and variations in the characters of nests already enumerated and described will be further-illustrated by specimens of the work of red eyed vireos (V'ireo olivaceous), wood pewees (Contopus vircns). and the hummingbirds These particular nests may be regarded as typical examples, but to give numerical results of any worth large numbers of specimens, drawn from every part of the known range of the several species would have to be examined.

Variation in nests of the red eyed rireo. We have seen that nests of the pendent type are much less variable in regard to the characters given above than in most of those built upon a basal support, and they are seldom found close to the ground. The supports chosen for such hanging nests are of necessity more uniform, and the nests themselves present a corresponding similarity in their measurements, as well as in the kinds and 
quantity of material used. This is well illustrated in nests of the red eyed vireo from Maine. New Hampshire and Ohio, as detailed in table III.

TABLE III

Variation in Nests of the Red Eyed Vireu

\begin{tabular}{|c|c|c|c|}
\hline No & 1 & 2 & 3 \\
\hline P'ace & $\begin{array}{l}\text { Ellsworth, } \\
\text { Ne. }\end{array}$ & $\begin{array}{l}\text { Northfield, } \\
\qquad \mathrm{H}\end{array}$ & $\begin{array}{c}\text { ('leveland Heights } \\
\text { Village. } 0\end{array}$ \\
\hline Diameter of cup & 2.3 incles & 2.2 unchen & 2.2 inches \\
\hline Depth of cup & 1.5 & 1.5 & 1.54 \\
\hline Uuter diameter & 36 & 31 & 3.1 \\
\hline Outer depth & 25 & 2.2 & 2.3 \\
\hline Thicknes of wall at base & 07 & 0.6 & 0.5 \\
\hline $\begin{array}{l}\text { Angle made by twig suj } \\
\text { ports }\end{array}$ & $85^{\circ}$ and $45^{\circ}$ & $\quad 60^{\circ}$ & $\quad 85^{\circ}$ \\
\hline Materialu & $\begin{array}{l}\text { Pluble bark strp- } \\
\text { mmgs, white coc- } \\
\text { won silk of } \\
\text { spid ers, and } \\
\text { paper }\end{array}$ & $\begin{array}{l}\text { Grape-vine and } \\
\text { borch bark, cloth, } \\
\text { wasp-nest paper, } \\
\text { spider cocoon sllk } \\
\text { and elm seeds }\end{array}$ & $\begin{array}{l}\text { Manly bark strips } \\
\text { of the grape and } \\
\text { rellow bire } \\
\text { rootlets, threatl } \\
\text { and spiders'slk. }\end{array}$ \\
\hline Lining of cups & Pine needles. & $\begin{array}{l}\text { Crape-vme bark } \\
\text { struped very tone }\end{array}$ & $\begin{array}{l}\text { Fine bark strips } \\
\text { and rootlets }\end{array}$ \\
\hline Means of surpension & $\begin{array}{l}\text { Mainly egg-cocoon } \\
\text { silk, with bask, } \\
\text { and paper }\end{array}$ & $\begin{array}{l}\text { Mainly cocoon } \\
\text { silk, bark strops. } \\
\text { and cloth }\end{array}$ & $\begin{array}{l}\text { Sijpder: ond } \\
\text { threat and bast }\end{array}$ \\
\hline $\begin{array}{l}\text { Situation } \\
\text { Height from ground }\end{array}$ & $\begin{array}{l}\text { Witch hazel } \\
15 \text { feet }\end{array}$ & Red matyle & Red nuaple \\
\hline & & & 20 tect \\
\hline
\end{tabular}

The building of nest No. 3 was watched from a good rantage point and will be later described This was the pororest in point of construction, and not having been preserved until after some time, it is somewhat damager1. The others are perfect, and brand new in appearance. Attention is particularly called to the practical identity in the measurements of their inner walls, as well as in their other essential characters While a greater series would unquestionably show more marked differences, we should not expect the variations to le very great. The chief apparent differences, though of no real importance, appear when these nests are riewed from their under sides, No. 3 being weathered to a dark gray, while No I (see fig. 9, part I), which is frescoed all over with paper and floss silk, is nearly white in consequence This silk, which was stolen from the egg cocoons of spiders, and when not bleached, is of a light cream color, is not only drawn out to secure every part of the 
surface, but is felted over the forked twigs to form a very serviceable support; there is almost enough silk to make a spool of thread. Nest No. 2 is intermediate in this respect, being grayish brown, and flecked with spiders' silk and birch bark curls. The last of the three nests suffered from being built in too wide a crotch, without the aid of a subordinate twig as in No. I, to reduce the angle. The strength of suspension, which seemed to satisfy the builder, was so weak that it had to be reinforced to save her eggs.

Variations in pewee's nests. The wood pewee, like the hummingbirds, treats the outer wall of its nest in a highly peculiar

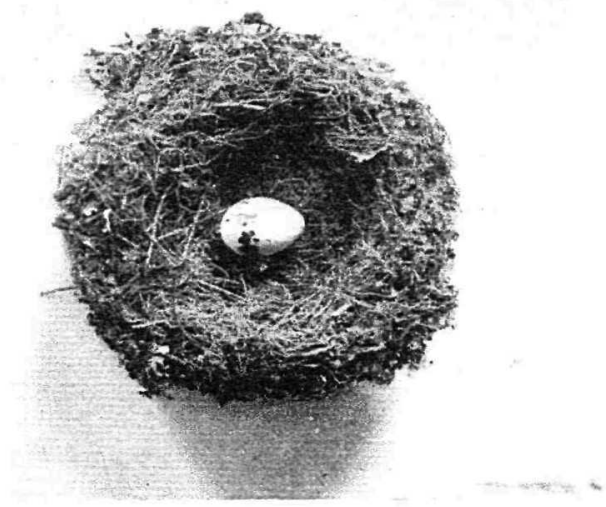

Figure 13-Nest of wood pewee (New Hampshire) to illustrate uniform treatment of diverse building materials. See No. 1, table IV, and compare figure 14. Egg inserted to mark level of cup.

manner, by frescoing it with lichens, or similar vegetable substances, thus rendering it inconspicuous, and done as some think for the purpose, or by way of ornament.

Of the two nests of this pewee available, the first (fig. I3) was saddled to the horizontal branch of an apple tree of an orchard in New Hampshire, within easy reach of pine and hemlock woods; the dimensions in either case are given in table III. It is rather bulky for the bird, and is wholly composed of four kinds of material, light green usnea moss, which is often seen hanging in streamers from the dying branches of crowded pines in damp 
situations, interworked with very fine twigs of hemlock, while the outer wall is incrusted with gray lichens, and flossed over with spiders' silk.

The Ohio nest (fig. I4) presents quite a different appearance. in both bulk and quality, though agreeing with the first in all

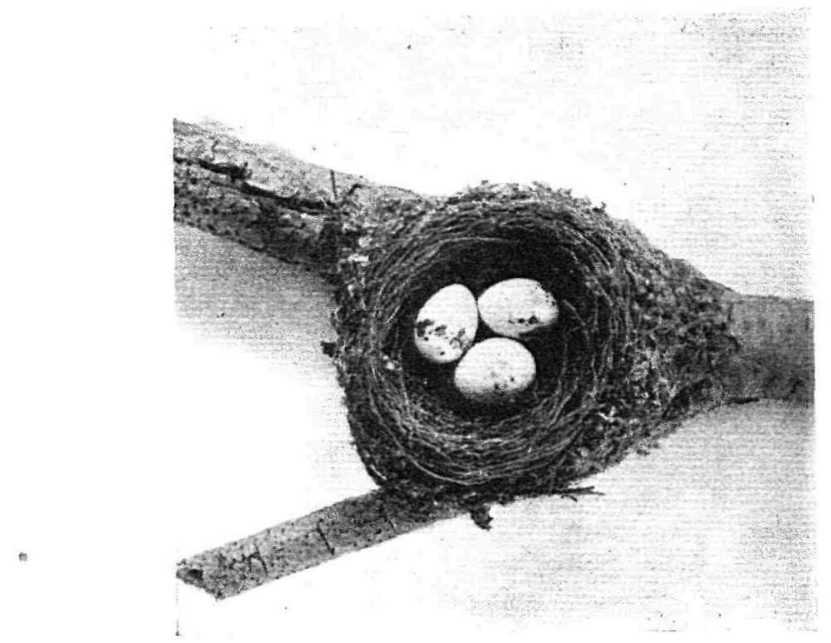

Fignue 14-Nest and eggs of the wood pewee (Ohio). Photographed to same scale as figure 13 , which see, and also No. 2, table IV.

TABLE IV

Showing Variations in Nests of the Wood Pewee

\begin{tabular}{|c|c|c|}
\hline No.......................... & 1 & 2 \\
\hline Place . . . . . . . . . . . . . . . . . & Northfield, N. H. & Euclid, $O$. \\
\hline 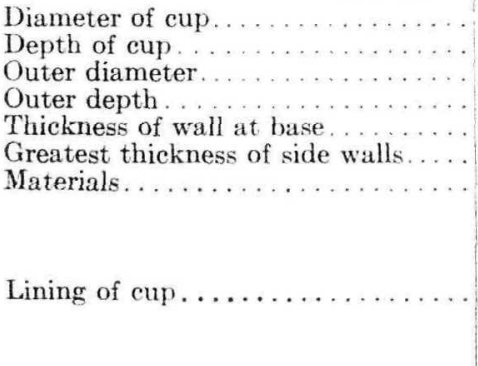 & $\begin{array}{l}\begin{array}{l}1.7 \text { inches } \\
0.7 \text { " } \\
3.4 \\
1.7 \\
0.9 \\
1.3\end{array} \\
\text { Usnea, hemlock twigs, } \\
\text { lichens, and spiders" } \\
\text { silk. } \\
\text { Light green usnea. } \\
\text { Horizontal (dead?) } \\
\text { branch of apple. }\end{array}$ & $\begin{array}{l}1.7 \text { inches } \\
0.8 \text { “ } \\
2.8 \text { “ } \\
1.8 \text {. } \\
0.9 \text {. } \\
0.9 \text {. } \\
\text { Bark strippings, ront- } \\
\text { lets, fine t w i g s, } \\
\text { weeds, lichens, and } \\
\text { spiders' silk. } \\
\text { Jet black rootlets. } \\
\text { Horizontal d e a d } \\
\text { branch of beech. }\end{array}$ \\
\hline
\end{tabular}




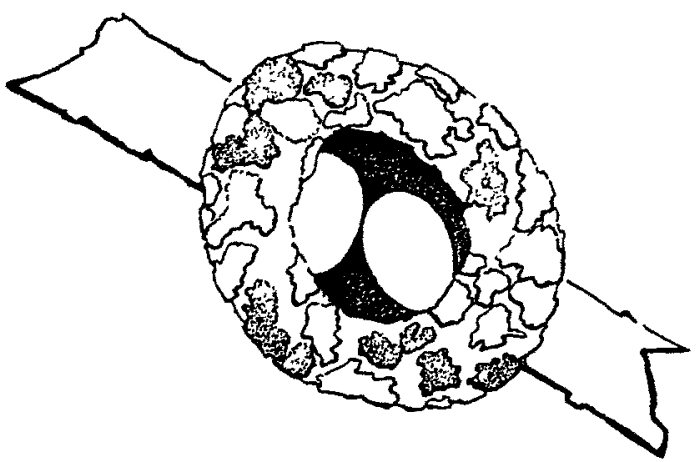

FigriRe 15- -iest and eggs of the ruby-throated hummingbird, attached to twig, seen from above, showing smoothed, felted wall, and fresco of lichens: patches represent bits of a light gray lichen, stippled when attached with dark under side up. Natural size.

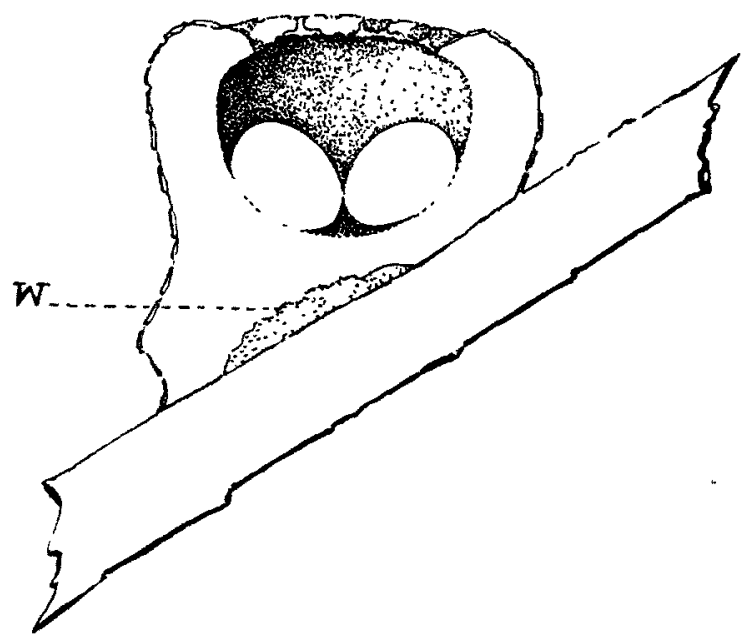

Figune 16-Sectional view of nest of ruby-throated hummingbird shown in figure 15 , illustrating symmetry of cup, the incrusting process carried to overarched rim, method of building up the lower side to compensate for incline of twig, and the wafer of saliva $\left(\mathrm{II}^{\circ}\right.$, ) by means of which the nest is glued to its support. Natural size.

essential measurements. It is mainly composed of fine grape bark strippings, and black, rather coarse and unmanageable rootlets; the latter form the inner wall exclusively, and being too springy to mold well, make a ragged rim, over which the scanty fresco of lichens has not been carried; its shallow cup is barely deep enough to hold the cream white, spotted eggs, which 
in this case stand out boldly from a black background. These nests, though dissimilar in outward appearance. agree in all essential respects, in the treatment of the outer and inner wall, and in the dimensions of the cup. The differences are unimportant, because plainly due to different environments.

Variations in Hummingbirds' nests. The hummingbirds' nests examined pertain to the ruby throat (Trochilus colubris), from the eastern states. the Anna (Calypte anna), the black-chinned (T. alexandri) and Allen's hummingbirds (Selasphorus alleni) from California, and the broad tailed hummer (S. platyccrcus) from the Santa Rita Mountains, Arizona. ${ }^{34}$

Hummingbirds build the smallest and most delicate nests known, ${ }^{35}$ but the examination of their work brings out the same kind of facts which we have seen in dealing with other and larger species. There seems to be not only a general agreement in the nests of different species and genera, but a striking uniformity in essential characters, and this is the more pronounced when different specimens of the same species are examined.

Hummingbirds exhibit the tendency to saddle their nests on small twigs and at a point where they fork (fig. 17); at times the base of their nest is continued around the main support, thus affording greater security. The ruby throat and Allen's hummingbird first spread an adhesive plaster of saliva on the chosen twig, and building upon the wafer thus formed literally glue their nest to its support like the swift Whether this is an invariable practise or not could not be decided from the material at my command. All build of the finest and softest regetable substances, in which the microscope reveals plant down and pappus of various kinds, the hairy coats of seeds, bud scales and the petals of flowers. In the nests examined animal products were limited to the nestling and small contour feathers of birds, a few horse hairs, and in one instance, peculiar short quills suggesting those of a hedgehog, but probably coming from a bird. (See fig. I 7.)

The materials of the nests examined, whatever their appearance or quality, are treated in a similar way, being felted and molded more or less compactly, and bound with spiders' silk.

\footnotetext{
34 For the privilege of examining these nests I am indebted to Dr. W. H. Valway, and Professor Hugh D. Pallister.

35 With the possible exception of the tree swifts: see p. 171, of part 1.
} 
IABLEL $V$

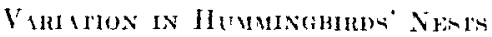

\begin{tabular}{|c|c|c|c|c|c|c|c|}
\hline Sipecien & Rubv throat & Rubs throat & Blach chunned & Black rhunned & Inn: & Broad-taled & NHens \\
\hline No & 1 & 2 & 3 & 4 & 5 & 6 & 7 \\
\hline $\begin{array}{l}\text { Place } \\
\text { Thine } \\
\text { Diameter of cup } \\
\text { pepth of cup } \\
\text { Outer diameter } \\
\text { Outer denth (avg) } \\
\text { Color of nest }\end{array}$ & 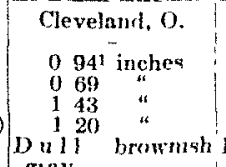 & 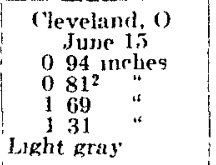 & 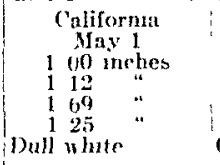 & 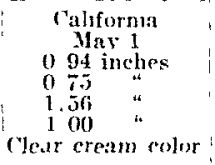 & 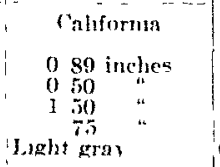 & 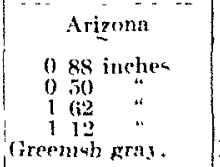 & $\begin{array}{c}\text { Cahfornia } \\
\text { April } 27 \\
093 \text { incliew } \\
062 \\
693 \\
103 \\
100 \\
\text { Dark gav." }\end{array}$ \\
\hline Materuals & $\begin{array}{l}\text { gray. } \\
\text { Fine plant down } \\
\text { chuefl }\end{array}$ & 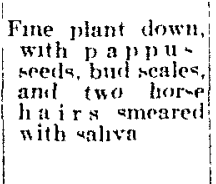 & $\begin{array}{l}\text { Fune folted whint } \\
\text { down }\end{array}$ & 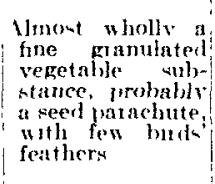 & 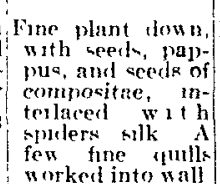 & 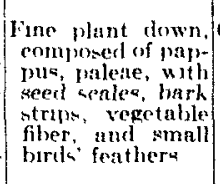 & 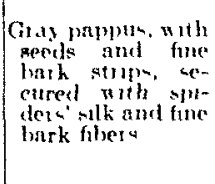 \\
\hline Lining (muner wall) & The same. & The same & The saner & The sume & The satme & $\begin{array}{l}\text { The nome, nith } \\
\text { down feathes of } \\
\text { nestlugs. }\end{array}$ & The sime. \\
\hline $\begin{array}{l}\text { Surface } \\
\text { wall })\end{array}(10$ t $t=1$ & $\begin{array}{l}\text { Smowth, frescoed } \\
\text { nith hit of lieh- } \\
\text { ens, secured face } \\
\text { up or down with } \\
\text { sphderg' silk. }\end{array}$ & $\begin{array}{l}\text { Smenth with gasy } \\
\text { lichen sorused } \\
\text { with } \\
\text { silk }\end{array}$ & 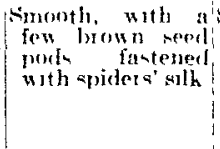 & $\begin{array}{l}\text { Simooth, with a } \\
\text { few small leaver } \\
\text { secured with allk }\end{array}$ & 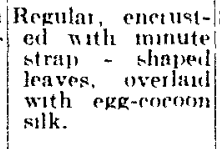 & 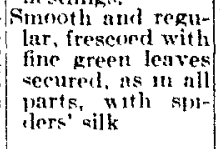 & 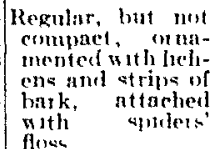 \\
\hline Powlion & On twig & $\begin{array}{l}\text { At branching of } \\
\text { beech twath. } \\
\text { inch to diameter }\end{array}$ & $\begin{array}{l}\text { At branehing of } \\
\text { twig, } 1 \text { inch } \\
\text { dianieter }\end{array}$ & $\begin{array}{l}\text { At branclung of } \\
\text { thig. } 3 \text { lach in } \\
\text { dianeter }\end{array}$ & $\begin{array}{l}\text { On flat rotedn of } \\
\text { bu thehme twig. } \\
2 \text { meh in dianse- }\end{array}$ & 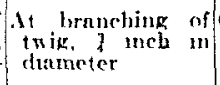 & 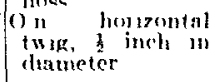 \\
\hline Fivation & $\mid \begin{array}{cc}\text { Nest material } \\
\text { partly earred } \\
\text { around stem Sa- } \\
\text { liva wafer } 3\end{array}$ & $\begin{array}{l}\text { By large wafer of } \\
\text { saliva at base }\end{array}$ & No aluva lastres & No saluva foxatue & No milusa wafer. & No aliva wafer. & $\begin{array}{l}\text { By rake of saliva } \\
\text { nt base }\end{array}$ \\
\hline
\end{tabular}

Probabls too lage, nest not quate nerfer

i vest detuched when mamiued 
The outer wall is smoothed and generally encrusted with fine vegetable substances, such as bits of gray lichen in the case of the ruby throat, or with minute leaves which were sometimes green when laid, with small fragments of bark, or the diminutive seed vessels of plants. A glance at the colors of such nests (table $\mathrm{V}$ ) followed by an examination of their supports and the scanty incrustation which their walls often receive, shows the hand of instinct as plainly here as in other nest building operations. That such birds often fresco the outer walls of their nests in such a way as to protect them by making them blend with their surroundings and at the same time adorn them by making

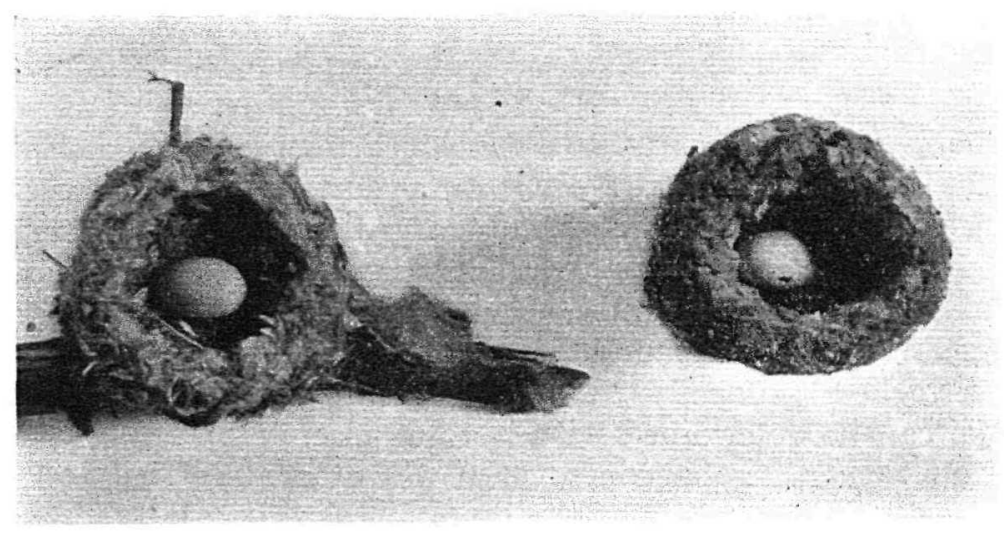

Figrre 17-Nest and egg of the anna hummingbird, attached at branching of twig by spiders' silk. See No. 5 , table V. Small quills piereing this nest below egg, and at left.

Figure 18 - Nest and egg of the ruby-throated hummingbird, detached from twig support. See No. 1, table $V$, and compare figure 15 : to the same scale as figure 17 .

them attractive to the human eye is not to be doubted, but it is hardly necessary to say that the evidence does not support the idea that they set about this labor with either end in view. Both nests of the black chinned hummingbird referred to (Nos. 3 and 4 , table $V$ ) were about as conspicuous as small objects could well be, in consequence of the material used and through lack of carrying the garnishing process to the proper stage.

The nesting materials are bound together and to their support with spiders' silk mainly, though a certain amount of saliva is 
liable to adhere to some of the increments, and has been detected in one or two instances, but the chief use of the salivary glue is in the wafer sometimes placed on the twig support (w. fig. I6). The saliva of the hummingbird, when dried out. becomes hard, brittle. and transparent like gum Arabic; when wet with cold water it swells and is opaque, but does not perceptibly dissolve, or at least not for a long time. No impression seemed to be made on bits of this substance experimented with. after inmersion for several days, but in hot water solution is both prompt and complete.

The ruby throat's nest (see especially No. I of table $T$ ) is often so perfectly modelled, that it appears as if pressed in a mold and stamped out of soft felt or papier mache, so true and even are its outer and inner walls and so perfect the rim of the cup (see figs. 15,16 and $r 8$ ), the only irregularity being seen at the base where the twig was enveloped. In this fine specimen of the hummer's work the whole outer surface is well encrusted with bits of a thin gray lichen down to the very brim, which is curiously bent inwards or overhung (fig. 16). The lichens are treated rather indifferently, being laid now with light gray face, now with brown underside uppermost (fig ${ }^{1} 5$ ), but they are attached uniformly throughout with spiders' silk, and so far as can be determined with nothing else.

Eighty years ago a controversy was started in England on the nest building habits of the hummingbirds, Audubon having affirmed that the ruby throat of America glued the lichens in place by means of saliva. Charles Waterton, his great and unreasonable adversary at that time, maintained that this was impossible, since the rery first rain would undo the work of the salivary gland.

Audubon's account of the ruby throat's nest which was challenged by Waterton, was as follows: $:^{36}$ "the external parts being formed of a light gray lichen found on the branches of trees, or on decayed fence-rails, and so neatly arranged round the whole nest, as well as to some distance from the spot where it is attached, as to seem part of the branch or stem itself.

${ }^{36}$ Op. cit , vol. 1. p. 25. For Waterton's attack, see "Mr. Audubon and his work, the Biography of Birds." Loudon's Magazine of Naturat History. London, 1834, vol. vii, $p$ 67-74. followed by four distinct articles, the third on the Hummingturd (p. 67-71). 
These little pieces of lichen are glued together with the saliva of the bird.'

It now seems that both sides to this controversy were partly right and partly wrong. When we remove some of the incrustation from the outer wall of the ruby throat's nest and examine it mounted in cold water under the microscope, the fibrous matter is seen to consist of two kinds, namely regetable fibers, such as plant hairs, and strips of bast, and others of animal origin; the latter, though extremely attenuated, prove to be spiders' silk. for no change is produced by boiling the water; the lichens, moreover, are lightly secured, and show no trace of saliva before or after removal. We must therefore infer that the only effective use which this hummingbird makes of its salivia in such operations is in the wafer with which its nest is sometimes if not regularly glued to its twig support. What is true of this :pecies seems to hold for others. although the wafer was found only in the anna and the ruby throat. The egg cocoon or even the web of a spider is quite as serviceable to them as to a wood pewee or a vireo. If it is true, as Audubon asserts, that lichens are attached over the branch at some distance from the nest, the fact is rery interesting, but this did not occur in any of the nests examined.

That certain hummingbirds which build hanging and swaying nests, sometimes compensate them by the addition of weights in the form of stones or lumps of earth. has been more than once reported, and a specimen of this kind may be seen in the British Museum. We regard such singular acts as strictly analogous to building the base of a nest around its support, or in favoring one side when the branch is inclined (see fig. I6), and thus bringing the cup of the nest into an upright position whatever the angle, or indeed in sticking the nest to its twig by means of an adhesive wafter. The structure and position of these birds in relation to their general habits warn us of the folly of reading a high degree of forethought and intelligence into any such acts, however remarkable. 